\title{
Temporal Variation in Natural Gas Seep Rate and Influence Factors in the Lingtou Promontory Seep Field of the Northern South China Sea
}

\author{
Pengfei $\mathrm{Di}^{1,3}$, Dong Feng ${ }^{1}$, and Duofu Chen ${ }^{1,2,3, *}$ \\ ${ }^{1}$ Key Laboratory of Marginal Sea Geology, South China Sea Institute of Oceanology, \\ Chinese Academy of Sciences, Guangzhou, China \\ ${ }^{2}$ Key Laboratory of Marginal Sea Geology, Guangzhou Institute of Geochemistry, \\ Chinese Academy of Sciences, Guangzhou, China \\ ${ }^{3}$ Sanya Institute of deep sea science and Engineering, Chinese Academy of Sciences, Sanya, China
}

Received 5 July 2013, revised 29 April 2014, accepted 30 April 2014

\begin{abstract}
Natural hydrocarbon seeps in marine environment are important sources of methane and other greenhouse gases into the ocean and the atmosphere. This greenhouse gas seepage influences the global methane budget and global climate change. Hydrocarbon seeps on the shallow seabed produce a near-shore gas bubble zone along the western coast of Hainan Island, in the northern South China Sea. However, few studies on the quantitative value of the methane flux and on temporal variation and influence factors of hydrocarbon seeps have been conducted until now. This study describes the results of continuous gas vent measurements for 420 hours on the seabed of the Lingtou promontory shore. The amount of gas released from a single gas vent was $30.5 \mathrm{~m}^{3}$ during the measurement period. The gas flow rate ranged from $22-72 \mathrm{~L} \mathrm{~h}^{-1}$, with an average rate of $53.4 \mathrm{~L} \mathrm{~h}^{-1}$. The time series analyses of the 420-hour record clearly show three principal tidal components with periods of 5.4, 4.6, and 2.4 hours, which are the main factors controlling the gas flow rate. Low flow rates were associated with high tide and high flow rates associated with low tide. A 1 -m increase in seawater height results in a decrease of $20-30 \mathrm{~L} \mathrm{~h}^{-1}$ or $35-56 \%$ of the hourly flow rate. Therefore, the changes in gas volume escape from the pore could be attributed to the hydrostatic pressure effect induced by water depth. This dominant mechanism controlled pore activation as well as the gas flow rate, suggesting that in the marine environment, especially the shallow-water shelf area, sea level changes may result in great variations in methane release into the ocean and atmosphere.
\end{abstract}

Key words: Hydrocarbon seep, Methane flux, Time series, Tidal effect pore activation, South China Sea

Citation: Di, P., D. Feng, and D. Chen, 2014: Temporal variation in natural gas seep rate and influence factors in the Lingtou promontory seep field of the northern South China Sea. Terr. Atmos. Ocean. Sci., 25, 665-672, doi: 10.3319/TAO.2014.04.30.01(Oc)

\section{INTRODUCTION}

Hydrocarbon seeps in marine environments are widely distributed across the seabed of nearly all continental margins (Judd et al. 2002; Judd 2003; Campbell 2006; Judd and Hovland 2007). Marine hydrocarbon seeps represent an important pathway by which natural gases, primarily methane, are released from the lithosphere into the hydrosphere and atmosphere. Marine hydrocarbon seeps are not only important local and regional sources of pollution but also might be an important factor impacting global climate change (Dimitrov 2003; Etiope and Milkov 2004; Etiope et

\footnotetext{
* Corresponding author

E-mail: cdf@gig.ac.cn
}

al. 2008). This is because methane is a strong greenhouse gas with a greenhouse effect that is approximately twenty times that of equal-quality carbon dioxide. The amount of methane discharged into the atmosphere through marine seeps is approximately $20 \mathrm{Tg} \mathrm{yr}^{-1}$ (Judd 2004; Etiope 2009), contributing approximately half of the global geological emissions of $40-60 \mathrm{Tg} \mathrm{yr}^{-1}$ of methane (Etiope and Milkov 2004; Etiope et al. 2008; Etiope 2009). Therefore, an accurate estimate of the amount of methane released from hydrocarbon seeps into the ocean and atmosphere is of great importance in understanding the role of hydrocarbon seeps in regional and global climate change and in the global carbon budget. However, progress in quantifying the amount of methane released into the ocean and atmosphere through this pathway 
has been hindered by the uncertainties involving the total area involved in active seepage and the temporal variability in seep intensity and activity.

In recent years, much attention has been paid to the long-term in-situ and on-line observations of the methane flux and the spatio-temporal variability at various hydrocarbon seep locations, e.g., Bush Hill of Mexico, Coal Oil Point seep field of the Santa Barbara channel, Hydrate Ridge, the Black Sea and Hikurangi Margin of New Zealand (Roberts et al. 1999; Tryon and Brown 2001, 2004; Boles et al. 2001; Torres et al. 2002; Tryon et al. 2002; Leifer and Boles 2005a, b; MacDonald et al. 2005; Vardaro et al. 2006; Solomon et al. 2008; Sahling et al. 2009; Krabbenhoeft et al. 2010; Leifer et al. 2010; Linke et al. 2010; Römer et al. 2012a, b; Etiope et al. 2013). The preliminary results indicate that the flux and material associated with hydrocarbon seeps are both spatial and temporal in nature (Tryon et al. 2002; Tryon and Brown 2004; Leifer and Boles 2005b; Solomon et al. 2008). The factors influencing the gas flux rate include tidal force, ocean swell, storm surges, tectonic processes, haline convection, biological pumping and transient discharge of subsurface gas reservoirs, bottom current velocities and near-surface sediment hydrology (Henry et al. 1992; Davis et al. 1995; Wang and Davis 1996; Orange et al. 1997; Wallmann et al. 1997; Suess et al. 1998; Tryon et al. 1999; Boles et al. 2001; Aliani et al. 2004; Leifer and Boles 2005b; Forrest et al. 2005; Talukder 2012).

The Yinggehai Basin is a Cenozoic era oil-gas basin in the north shelf of the South China Sea, characterized by abundant hydrocarbon seeps, pockmarks and mud volcanoes at the seabed (Huang et al. 2003, 2004, 2005, and 2009). Over 120 hydrocarbon seeps have been found on the seafloor at water depths less than $50 \mathrm{~m}$ along the eastern edge of the Yinggehai Basin near the western coast of Hainan Island. The gas rises from the seeps to the sea surface to form a near-shore bubble zone (Fig. 1) (Huang et al. 2009). The gas, primarily thermogenic methane, originates from the Miocene hydrocarbon source rock in the central depression of the Yinggehai basin. The total gas flux emitted from these hydrocarbon seeps is estimated to be $294-956 \mathrm{~m}^{3} \mathrm{yr}^{-1}$ (Huang et al. 2009). However, the gas flux of hydrocarbon seeps and its variation characteristics with time offshore Yinggehai have not been accurately qualified. The hydrocarbon seep activation mechanisms on the seafloor have also not been revealed.

To quantify the gas flux from hydrocarbon seeps, an in-situ and on-line gas flux measuring (GFM) device was deployed over an active hydrocarbon seep on the near-shore seafloor of the Lingtou promontory in the April - May period of 2012. We present a high-resolution time series of the natural gas flow rates from the Lingtou promontory seep field in the northern South China Sea. These data allow us to examine the hourly seepage variability and compare it with the water depth record, as well as explore the mechanism causing changes in the hydrocarbon seep flux at the Lingtou seep field.

\section{GFM DEVICE AND SUBMARINE OBSERVATION}

An in-situ, on-line GFM device was used to quantify the gas flux at the hydrocarbon seeps using the volume exchange method (Fig. 2). The GFM device operates as follows: when rising gas bubbles emitted from hydrocarbon seeps enter the

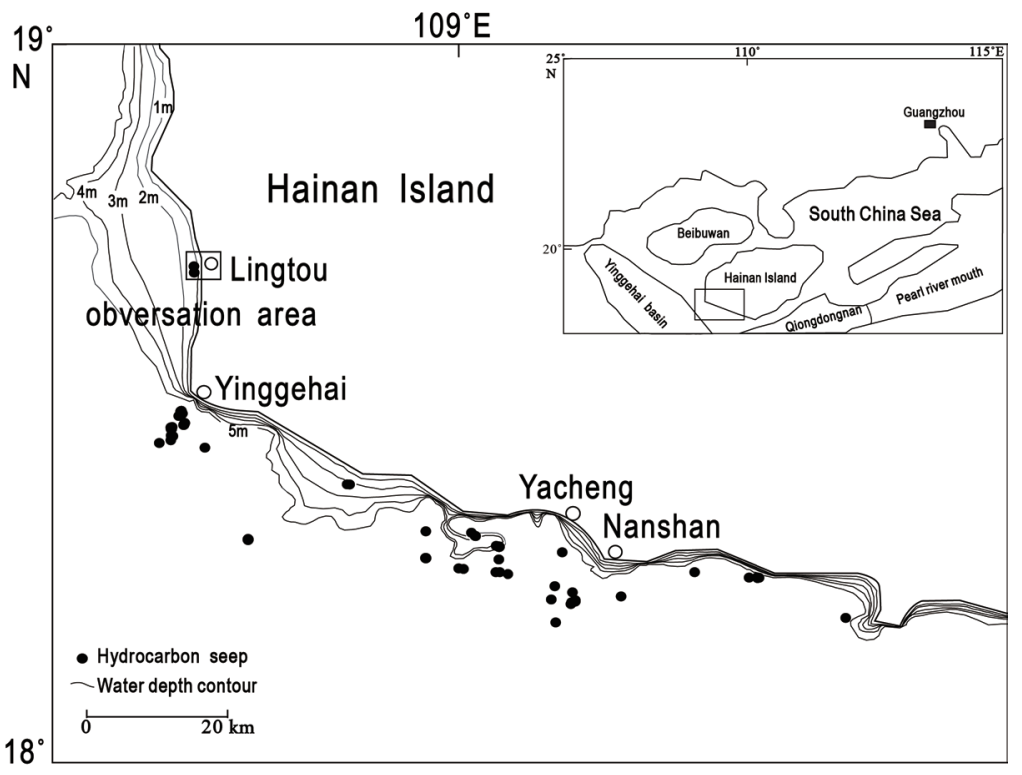

Fig. 1. The distribution of the near shore hydrocarbon seeps and location of the in-situ and on-line hydrocarbon seep observation area near Lingtou promontory. 


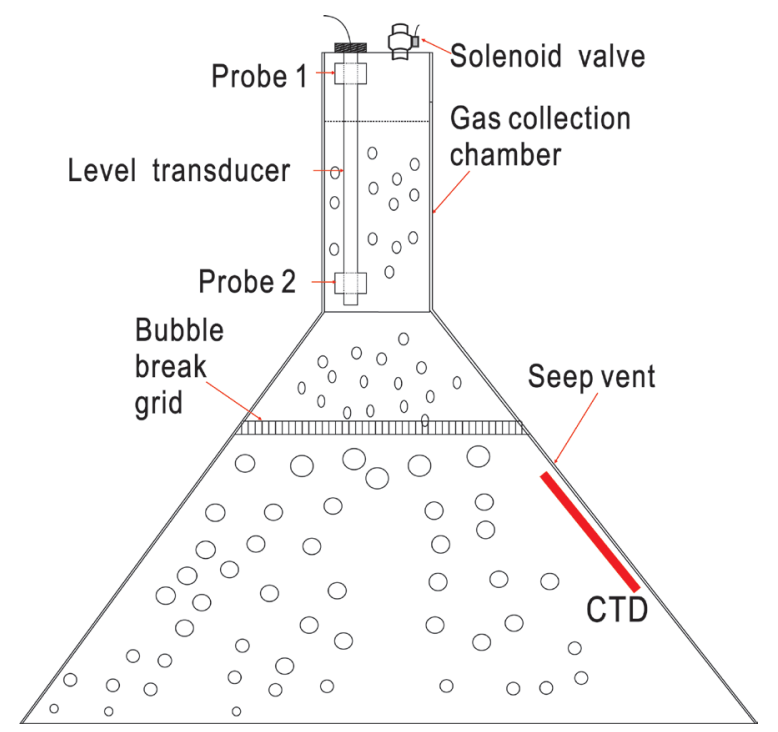

Fig. 2. Photograph and schematic diagram of the in-situ and on-line measuring device. The volume within the gas collection chamber is $1.72 \mathrm{~L}$. A solenoid valve was used to control the gas collection and emptying. The liquid level sensor indicates the changes in water level and controls the solenoid valve opening and closing. A conical seep tent was used to collect gas bubbles emitted from hydrocarbon seep. A bubble-breaking grid was used to prevent debris or biological organisms from clogging the gas collection chamber. CTD: ConductivityTemperature-Depth system.

gas collection chamber, the water in the chamber will be expelled downward in an equal volume. When the water level drops to the lower probe level (Probe 2) in the chamber, the valve will be opened by an automatic control system and the gas within the chamber will then be emptied instantly and filled again by seawater. The time and frequency of the valve opening are recorded automatically. When the seawater level rises up to the higher probe level (Probe 1), the valve will automatically close and the GFM will then start its next round of gas collection. The gas flux is calculated based on the number of valve openings and the chamber volume. The relative error is $\pm 1.0 \%$ (Di et al. 2012).

The water depth data were obtained from a CTD (Conductivity-Temperature- Depth) system mounted on the GFM device. The data-logging interval was set at 1 minute and the resolution was $0.01 \mathrm{~m}$. The water depth data for the seep area was calculated based on the instantaneous bottom pressures measured by the CTD system and adjusted for the local conditions by adding the distances between probe and seabed and by subtracting the local atmosphere pressure value.

The Lingtou promontory seep field is one of the more active natural hydrocarbon seepage areas on the near shore seafloor of the Yinggehai basin. Over 20 individual hydrocarbon seeps emit gases within an area approximately 580 by $160 \mathrm{~m}$ at a water depth ranging from $3-20 \mathrm{~m}$, which is located $300 \mathrm{~m}$ offshore near Lingtou promontory in Hainan Province. Gas bubbles (each up to $1-2 \mathrm{~cm}$ in diameter) con- tinuously emit from the hydrocarbon seeps on the seafloor. Gas bubbles emitting from the seep vent rise to the sea surface rapidly and release natural gases into the atmosphere. The GFM device was set on the seafloor in the Lingtou promontory seep field with four anchors, placed over an active seep vent $\left(18^{\circ} 41^{\prime} 15.7^{\prime \prime} \mathrm{N}, 108^{\circ} 41^{\prime} 37.0^{\prime \prime} \mathrm{E}\right)$ on 22 April 2012, and recovered on 21 May 2012 by divers.

\section{RESULTS}

\subsection{Gas Flow and Water Depth Data}

Due to a power source malfunction the GFM device only recorded hydrocarbon seep gas flow data continuously for 420 hours from at 15:00 on 22 April 2012 to 4:00 on 10 May 2012. The GFM device calculated the hourly gas flow rate by accumulating the opening numbers during the $1^{\text {st }}$ hour, with the hourly gas flow rate then converted into the standard gas flow rate.

Figure 3 shows the continuously measured water depth and hydrocarbon seep gas flow time series using the CTD system and GFM device, respectively, for 420 hours. The water depths at the observation seep vent ranged from $2.4-4.6 \mathrm{~m}$. The observed average tidal difference for the entire study period was $1.4 \mathrm{~m}$. The observed maximum and minimum tidal differences were 2.1 and $0.7 \mathrm{~m}$, respectively. The gas flux increased with the water depth (Fig. 3). The gas flow rate ranged from $22.36-72.24 \mathrm{~L} \mathrm{~h}^{-1}$ (Fig. 3), which are much higher than the $0.28-0.43 \mathrm{~L} \mathrm{~h}^{-1}$ measured by collecting gas bubbles from the water surface using a funnel (Huang et al. 2009). The amount of gas released from the hydrocarbon seep for the 420 -hour period was $30.5 \mathrm{~m}^{3}$, resulting in a calculated gas flux of $6.36 \times 10^{2} \mathrm{~m}^{3} \mathrm{yr}^{-1}$. The gas bubble composition from the seeps is dominated by thermogenic methane (> 70.79\%) with $\delta^{13} \mathrm{C}$ from $33.91-38.24 \%$ o PDB (Huang et al. 2009). The gas bubbles $(d=1-2 \mathrm{~cm})$ contained about $95 \%$ methane upon reaching the sea surface (McGinnis et al. 2006). Therefore, applying this gas flux to the eastern edge area of the Yinggehai Basin, which is known to contain approximately 120 hydrocarbon seeps, a total of $4.84 \times 10^{4}$ to $6.84 \times 10^{4} \mathrm{~m}^{3} \mathrm{yr}^{-1}$ (or $2.163 \times 10^{6}$ to $3.057 \times 10^{6} \mathrm{~mol} \mathrm{yr}^{-1}$ ) of methane is speculated emitted if each hydrocarbon seep emitted a similar gas flux. This amount of methane emitted is much higher than the preliminary estimated range from $294-956 \mathrm{~m}^{3} \mathrm{yr}^{-1}$ (Huang et al. 2009). Furthermore, this speculated methane flux is also much greater than the estimated fluxes from other gas hydrate and upwelling study areas offshore SW Taiwan in the South China Sea (Chuang et al. 2006, 2010).

\subsection{Gas Flow Rate and Water Depth}

Figure 3 shows the variation in gas flow measured continuously for $\sim 420$ hours by the GFM device at the seep. The data exhibited a repeated daily gas flow pattern. The 
range of variation in the gas flow decreased gradually with time until 3 May, after which it increased gradually.

To quantify the periodic variation in the natural gas flow rate and its control factor, we computed power spectrum of the gas flow rate time series (Fig. 4). The ensemble of all the $\sim 420$ hours of recorded gas flow time series was tapered with a Hanning window and then transformed via a fast Fourier transform (FFT) algorithm. For frequencies $f$ less than $\sim 1.0$ cycles per day (cpd), the spectral amplitude of $q$ decreased strongly with $f$ (Fig. 4). At high $f$, the amplitude was approximately consistent with white noise, except for 2 bands where strong peaks were evident, one at $\sim 4.5 \mathrm{cpd}$ and the other at $10 \mathrm{cpd}$. These peaks, corresponding to the dominant mixed tidal components, were the only significant sinusoidal components present, based on the 95\% confidence limits. The FFT of the data also verified that no sinusoids were present at other resolved frequencies. The corresponding spectral resolution was $f=0.3 \mathrm{cpd}$. Within the time series resolution, the center frequencies of these peaks correspond to the three dominant mixed tidal constituents: $\mathrm{O}_{1}$ with a period 5.4 hours, $\mathrm{O}_{2}$ with a period 4.6 hours, and $S_{1}$ with a period 2.4 hours. All three peaks were well resolved, exceeding the surrounding spectral levels by over an order of magnitude.

To quantify the changing water depth effect on gas flow rates, three 1-day intervals (28 April, 3 May, and 9 May) were chosen from 18 days that exhibited particularly large differences between high and low tide. The average tidal ranges for the three days, 28 April, 3 May, and 9 May, were approximately $1.3,0.8$, and $1.8 \mathrm{~m}$, respectively. Although the tidal differences in the three days were quite unequal, the related gas flow rate $\mathrm{R}^{2}$ coefficient and water depth were high $\left(R^{2}=0.976,0.9725\right.$, and 0.9595 for 28 April, 3 May, and 9 May, respectively).

Figure 5 shows the gas flow rates exhibit a significantly negative correlation with the water depth in the three days chosen. Gas flow and water depth data were picked once every 10 minutes. In our calculation the gas flow is the mean flow rate during the time when the GFM device measures natural gas flow. The water depth is the mean water depth during the time required for the GFM device to collect gas. In the three days high tide correlated with low flow and low tide correlated with high flow (Fig. 5). The correlation $\left(R^{2}=0.914\right)$ between the gas flow and water depth suggests that the natural gas flow rate is controlled primarily by the water depth (Fig. 5). Each additional meter of sea height represents a hydrostatic pressure increase of $10^{4} \mathrm{~Pa}$ and a natural gas flow rate decrease of $20-30 \mathrm{~L} \mathrm{~h}^{-1}$.

\section{DISCUSSION}

The bubble formation criterion on the seabed, where the fracture pressure, $P_{F}$, must be greater than the combination of hydrostatic pressure, $P_{H}$, and the La Place pressure, $P_{S T}$, from the surface tension force, i.e., $P_{F}>P_{H}+P_{S T}$. The time to form a bubble depends on the flow in the pore and the fracture, the emitted bubble's volume and hydrostatic pressure $P_{H}$. The bubble radius, $r$, is directly proportional to the pore and fracture throat size, and inversely proportional the surface tension, $P_{S T}$ (Boles et al. 2001; Leifer et al. 2005b). The larger the fracture or pore size, the less energy is required to overcome the capillary pressure and the surface tension, making the bubbles easier to produce, and of course, the release of a large bubble causes a greater decrease in $P_{F}$. Conversely, the smaller the pore throat size in the sediment, the more energy required to overcome the capillary pressure and the surface tension, resulting in increased difficulty in producing gas bubbles.

The gas flow time series and the correlation analysis indicate that the natural gas flow migrating from the leaking gas reservoir along the fault and fracture pathway is influenced by the hydrostatic pressure $P_{H}$. The decrease in gas flow corresponds to the increase in the water depth. Spectral analysis of the gas flow time series clearly indicates a mixed tidal cycle frequency. In general, the hydrostatic pressure is induced by both oceanic tides and swell. Leifer

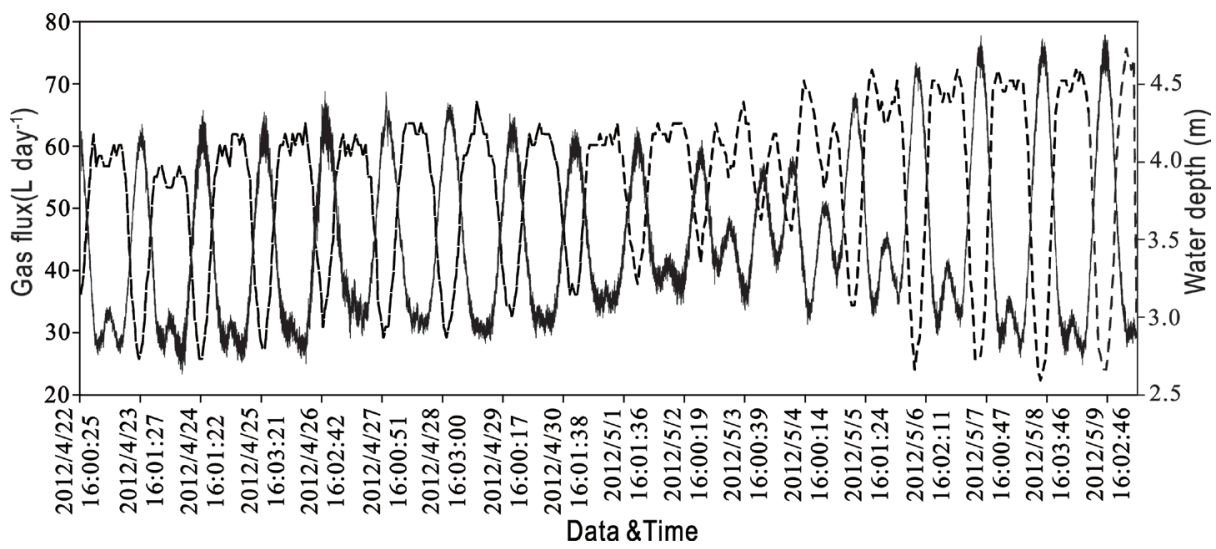

Fig. 3. Time-series of gas flow rate (dotted line) and water depth (real line) at the Lingtou promontory seep field. 


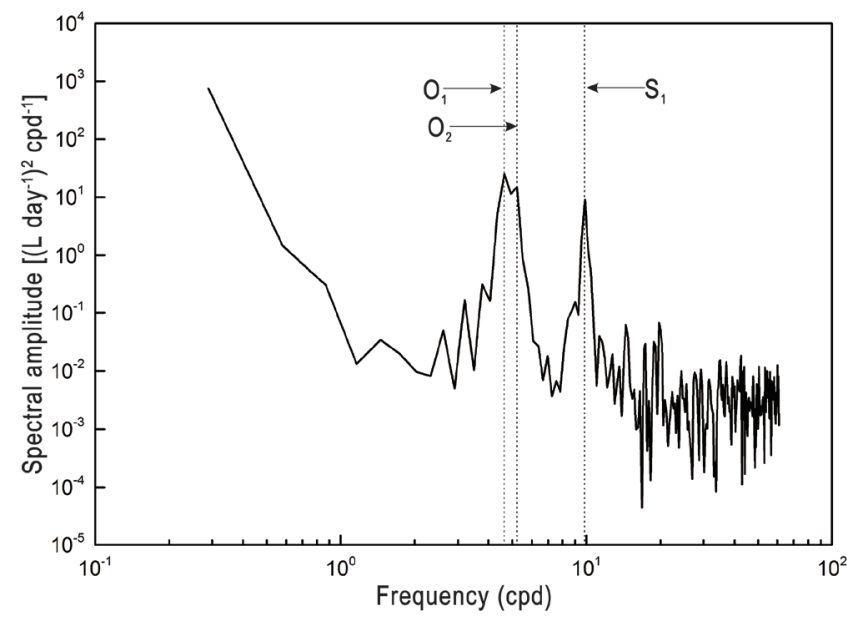

Fig. 4. Auto-spectrum of seepage rate $q$ during the period from 22 April to 10 May 2012.

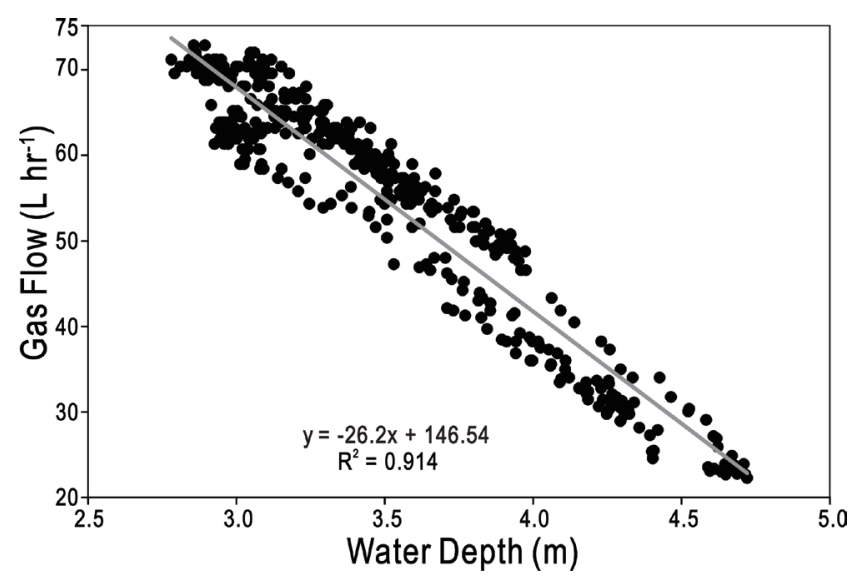

Fig. 5. Comparison between the gas flux from the hydrocarbon seep and the water depth.

et al. (2005b) proposed that the bubble emission rate or the seep gas flux is related to the bubble size, the gas flow in the fault or fracture, and the hydrostatic pressure $P_{H}$. Therefore, any process that changes the flow, the bubble size, or $P_{H}$ will change the bubble emission rate or the seep gas flux. Boles et al. (2001) and Leifer et al. (2005b) proposed three possible mechanisms that can explain how the hydrostatic pressure, $P_{H}$, variation changes the seep gas flux. The first is that hydrostatic pressure induces pore throat or fracture activation and deactivation (pore activation). The second is that the marine sediment surrounding the fracture and fault adsorbs or desorbs gas, depending upon hydrostatic pressure, a process termed "gas charging". The third is that the fracture dimension and the flow resistance are affected by the hydrostatic pressure, a process termed "fracture forcing".

The Lingtou promontory seep field contains numerous vents that span many sizes and connectivity paths. Natural gas migrates as a continuous phase from the leaking gas res- ervoirs along the fault or fracture pathway to the seafloor (Brown 2000). The seep natural gas erupts as bubble plumes to the seafloor, with each plume exhibiting different seep gas composition, bubble size, and bubble formation time characteristics. Our results reveal that the gas flow in the fracture increases rapidly with the decrease in hydrostatic pressure, $P_{H}$. Thus, the bubble formation time decreases and the number of bubbles formed increase, while the fracture pressure decreases until equilibrium is restored (Fig. 4). However, due to the fracture resistance, $P_{F}$ may not drop as fast as $P_{H}$, and thus the current inactive seep vents become active, so the gas flux gradually increases. Conversely, an increase in $P_{H}$ has the opposite effect (Leifer et al. 2005b). Therefore, pore activation is the dominant factor controlling the variation in gas flux.

Natural gas flow in the Lingtou promontory seep field exhibited a negative correlation with the water depth (Fig. 5). Similar results were also observed at other typical hydrocarbon seeps (Orange et al. 1997; Boles et al. 2001; Torres et al. 2002; Forrest et al. 2005). The results report 35 - 56\% change in the gas flow with the water depth in the Lingtou promontory seep field when the water depth changes $1 \mathrm{~m}$. These observed changes in gas flow indicate that the gas flow is apparently sensitive to hydrostatic pressure changes, so a smallscale change in water depth can significantly change the gas flow. Consequently, if the large-scale sea level changes, the large inventory of natural gas in the continental shelf seabed, primarily methane, may leak from the marine sediment into the ocean and atmosphere, thereby significantly affecting the global carbon cycle and global climate change.

\section{CONCLUSION}

For the first time, this study quantified the gas flux, variation and influence factors of a hydrocarbon seep in the Lingtou promontory seep field in the northern South China Sea over a period of 420 hours. The quantity of gas released from the hydrocarbon seep was $30.5 \mathrm{~m}^{3}$ for the observation period. The measured gas flow rate ranged from $22-77 \mathrm{~L} \mathrm{~h}^{-1}$, and the average velocity was $53.4 \mathrm{~L} \mathrm{~h}^{-1}$. The results indicate that the variation in water depth caused the gas flow to vary by $44-59 \%$ around the mean flow. The gas flow rate time series power spectrum clearly indicates three mixed tidal components. The correlation analysis of the water depth and gas flow indicates that the gas flow is controlled by the hydrostatic pressure induced by the water depth. Based on the seep frequency response, pore activation is the dominant control factor that changes the gas flow. Therefore, in the marine environment, especially the shallow-water shelf area, the sea level change could cause large variations in methane release at the seabed into the hydrosphere and atmosphere.

Acknowledgment This study was partially supported by the 
National Natural Scientific Foundation of China (41306045 and 91228206), the Knowledge Innovation Project of the Chinese Academy of Sciences (SQ201110), the "Hundred Talents Program" of CAS, and Key Laboratory of Renewable Energy and Gas Hydrate, Chinese Academy of Sciences (y207k11001). Dr. Baojia Huang is appreciated for providing the gas seep coordinates. Furthermore, we thank the Editor and anonymous reviewers for their helpful comments that greatly improved the quality of this manuscript.

\section{REFERENCES}

Aliani, S., R. Meloni, and P. R. Dando, 2004: Periodicities in sediment temperature time-series at a marine shallow water hydrothermal vent in Milos Island (Aegean Volcanic arc, Eastern Mediterranean). J.Mar. Syst., 46, 109-119. doi: 10.1016/j.jmarsys.2003.11.015. [Link]

Boles, J.R., J. F. Clark, I. Leifer, and L. Washburn, 2001: Temporal variation in natural methane seep rate due to tides, Coal Oil Point area, California. J. Geophys. Res., 106, 27077-27086, doi: 10.1029/2000JC000774. [Link]

Brown, A., 2000: Evaluation of possible gas microseepage mechanisms. AAPG Bull., 84, 1775-1789, doi: 10.1306/8626C389-173B-11D7-8645000102C1865D. [Link]

Campbell, K. A., 2006: Hydrocarbon seep and hydrothermal vent paleoenvironments and paleontology: Past developments and future research directions. Palaeogeogr. Palaeoclimatol. Palaeoecol., 232, 362-407, doi: 10.1016/j.palaeo.2005.06.018. [Link]

Chuang, P. C., T. F. Yang, S. Lin, H. F. Lee, T. F. Lan, W. L. Hong, C. S. Liu, J. C. Chen, and Y. Wang, 2006: Extremely high methane concentration in bottom water and cored sediments from offshore southwestern Taiwan. Terr. Atmos. Ocean. Sci., 17, 903-920.

Chuang, P. C., T. F. Yang, W. L. Hong, S. Lin, C. H. Sun, A. T. S. Lin, J. C. Chen, Y. Wang, and S. H. Chung, 2010: Estimation of methane flux offshore SW Taiwan and the influence of tectonics on gas hydrate accumulation. Geofluids, 10, 497-510, doi: 10.1111/j.14688123.2010.00313.x. [Link]

Davis, E. E., K. Becker, K. Wang, and B. Carson, 1995: Long-term observations of pressure and temperature in Hole 892B, Cascadia accretionary prism. In: Carson, B., G. K. Westbrook, R. J. Musgrave, and E. Suess (Eds.), Proceedings of the Ocean Drilling Program, Scientific Results, Vol. 146 (Pt. 1), College Station, TX (Ocean Drilling Program), 299-311. doi: 10.2973/ odp.proc.sr.146-1 219.1995. [Link]

Di, P., Q. Chen, and D. Chen, 2012: In situ on-line measuring device of gas seeping flux at marine seep sites and experimental study. J. Trop. Oceanogr., 31, 83-87. (in Chinese)
Dimitrov, L. I., 2003: Mud volcanoes-a significant source of atmospheric methane. Geo-Mar. Lett., 23, 155-161, doi: 10.1007/s00367-003-0140-3. [Link]

Etiope, G., 2009: Natural emissions of methane from geological seepage in Europe. Atmos. Environ., 43, 14301443, doi: 10.1016/j.atmosenv .2008.03.014. [Link]

Etiope, G. and A. V. Milkov, 2004: A new estimate of global methane flux from onshore and shallow submarine mud volcanoes to the atmosphere. Environ. Geol., 46, 997-1002, doi: 10.1007/s00254-004-1085-1. [Link]

Etiope, G., K. R. Lassey, R. W. Klusman, and E. Boschi, 2008: Reappraisal of the fossil methane budget and related emission from geologic sources. Geophys. Res. Lett., 35, L09307, doi: 10.1029/2008GL033623. [Link]

Etiope, G., D. Christodoulou, S. Kordella, G. Marinaro, and G. Papatheodorou, 2013: Offshore and onshore seepage of thermogenic gas at Katakolo Bay (Western Greece). Chem. Geol., 339, 115-126, doi: 10.1016/j. chemgeo.2012.08.011. [Link]

Forrest, M. J., J. Ledesma-Vázquez, W. Ussler III, J. T. Kulongoski, D. R. Hilton, and H. G. Greene, 2005: Gas geochemistry of a shallow submarine hydrothermal vent associated with the El Requesón fault zone, Bahía Concepción, Baja California Sur, México. Chem. Geol., 224, 82-95, doi: 10.1016/j.chemgeo.2005.07.015. [Link]

Henry, P., J. P. Foucher, X. Le Pichon, M. Sibuet, K. Kobayashi, P. Tarits, N. Chamot-Rooke, T. Furuta, and P. Schultheiss, 1992: Interpretation of temperature measurements from the Kaiko-Nankai cruise: Modeling of fluid flow in clam colonies. Earth Planet. Sci. Lett., 109, 355-371, doi: 10.1016/0012-821X(92)90098-G. [Link]

Huang, B., X. Xiao, and X. Li, 2003: Geochemistry and origins of natural gases in the Yinggehai and Qiongdongnan basins, offshore South China Sea. Org. Geochem., 34, 1009-1025, doi: 10.1016/S0146-6380(03)00036-6. [Link]

Huang, B., X. Xiao, and W.Zhu, 2004: Geochemistry, origin, and accumulation of $\mathrm{CO}_{2}$ in natural gases of the Yinggehai Basin, offshore South China Sea. AAPG Bull., 88, 1277-1293, doi: 10.1306/04120403045. [Link]

Huang, B., X. Xiao, Z. Hu, and P. Yi, 2005: Geochemistry and episodic accumulation of natural gases from the Ledong gas field in the Yinggehai Basin, offshore South China Sea. Org. Geochem., 36, 1689-1702, doi: 10.1016/j.orggeochem.2005.08.011. [Link]

Huang, B., X. Xiao, X. Li, and D. Cai, 2009: Spatial distribution and geochemistry of the nearshore gas seepages and their implications to natural gas migration in the Yinggehai Basin, offshore South China Sea. Mar. Petrol. Geol., 26, 928-935, doi: 10.1016/j.marpetgeo.2008.04.009. [Link]

Judd, A. G., 2003: The global importance and context of methane escape from the seabed. Geo-Mar. Lett., 23, 
147-154, doi: 10.1007/s00367-003-0136-z. [Link]

Judd, A. G., 2004: Natural seabed gas seeps as sources of atmospheric methane. Environ. Geol., 46, 988-996, doi: 10.1007/s00254-004-1083-3. [Link]

Judd, A. G. and M. Hovland, 2007: Seabed Fluid Flow: The Impact on Geology, Biology and the Marine Environment, Cambridge University Press, Cambridge, UK, $475 \mathrm{pp}$.

Judd, A. G., M. Hovland, L. I. Dimitrov, S. García Gil, and V. Jukes, 2002: The geological methane budget at Continental Margins and its influence on climate change. Geofluids, 2, 109-126, doi: 10.1046/j.14688123.2002.00027.x. [Link]

Krabbenhoeft, A., G. L. Netzeband, J. Bialas, and C. Papenberg, 2010: Episodic methane concentrations at seep sites on the upper slope Opouawe Bank, southern Hikurangi Margin, New Zealand. Mar. Geol., 272, 71-78, doi: 10.1016/j.margeo.2009.08.001. [Link]

Leifer, I. and J. Boles, 2005a: Measurement of marine hydrocarbon seep flow through fractured rock and unconsolidated sediment. Mar. Petrol. Geol., 22, 551-568, doi: 10.1016/j.marpetgeo.2004.10.026. [Link]

Leifer, I. and J. Boles, 2005b: Turbine tent measurements of marine hydrocarbon seeps on subhourly timescales. J. Geophys. Res., 110, C01006, doi: 10.1029/ 2003JC002207. [Link]

Leifer, I., M. J. Kamerling, B. P. Luyendyk, and D. S. Wilson, 2010: Geologic control of natural marine hydrocarbon seep emissions, Coal Oil Point seep field, California. Geo-Mar. Lett., 30, 331-338, doi: 10.1007/ s00367-010-0188-9. [Link]

Linke, P., S. Sommer, L. Rovelli, and D. F. McGinnis, 2010: Physical limitations of dissolved methane fluxes: The role of bottom-boundary layer processes. Mar. Geol., 272, 209-222, doi: 10.1016/j.margeo.2009.03.020. [Link]

MacDonald, I. R., L. C. Bender, M. Vardaro, B. Bernard, and J. M. Brooks, 2005: Thermal and visual time-series at a seafloor gas hydrate deposit on the Gulf of Mexico slope. Earth Planet. Sci. Lett., 233, 45-59, doi: 10.1016/j.eps1.2005.02.002. [Link]

McGinnis, D. F., J. Greinert, Y. Artemov, S. E. Beaubien, and A. Wüest, 2006: Fate of rising methane bubbles in stratified waters: How much methane reaches the atmosphere? J. Geophys. Res., 111, C09007, doi: 10.1029/2005jc003183. [Link]

Orange, D.L., D. Saffer, and N. Maher, 1997: Tidally mediated fluid expulsion at a cold seep. Eos, Transactions American Geophysical Union 78, Fall Meet. Suppl. Abstract T31E-11.

Roberts, H. H., W. J. Wiseman, J. Hooper, and G. D. Humphrey, 1999: Surficial gas hydrates of the Louisiana continental slope-initial results of direct observations and in situ data collection. Offshore Technology Conference, Houston, Texas, doi: 10.4043/10770-MS. [Link]
Römer, M., H. Sahling, T. Pape, A. Bahr, T. Feseker, P. Wintersteller, and G. Bohrmann, 2012a: Geological control and magnitude of methane ebullition from a high-flux seep area in the Black Sea-the Kerch seep area. Mar. Geol., 319-322, 57-74, doi: 10.1016/j.margeo.2012.07.005. [Link]

Römer, M., H. Sahling, T. Pape, G. Bohrmann, and V. Spieß, 2012b: Quantification of gas bubble emissions from submarine hydrocarbon seeps at the Makran continental margin (offshore Pakistan). J. Geophys. Res., 117, C10015, doi: 10.1029/2011jc007424. [Link]

Sahling, H., G. Bohrmann, Y. G. Artemov, A. Bahr, M. Brüning, S. A. Klapp, I. Klaucke, E. Kozlova, A. Nikolovska, T. Pape, A. Reitz, and K. Wallmann, 2009: Vodyanitskii mud volcano, Sorokin trough, Black Sea: Geological characterization and quantification of gas bubble streams. Mar. Petrol. Geol., 26, 1799-1811, doi: 10.1016/j.marpetgeo.2009.01.010. [Link]

Solomon, E. A., M. Kastner, H. Jannasch, G. Robertson, and Y. Weinstein, 2008: Dynamic fluid flow and chemical fluxes associated with a seafloor gas hydrate deposit on the northern Gulf of Mexico slope. Earth Planet. Sci. Lett., 270, 95-105, doi: 10.1016/j.epsl.2008.03.024. [Link]

Suess, E., G. Bohrmann, R. von Huene, P. Linke, K. Wallmann, S. Lammers, H. Sahling, G. Winckler, R. A. Lutz, and D. Orange, 1998: Fluid venting in the eastern Aleutian subduction zone. J. Geophys. Res., 103, 2597-2614, doi: 10.1029/97jb02131. [Link]

Talukder, A. R., 2012: Review of submarine cold seep plumbing systems: leakage to seepage and venting. Terr. Nova, 24, 255-272, doi: 10.1111/j.13653121.2012.01066.x. [Link]

Torres, M. E., J. McManus, D. E. Hammond, M. A. de Angelis, K. U. Heeschen, S. L. Colbert, M. D. Tryon, K. M. Brown, and E. Suess, 2002: Fluid and chemical fluxes in and out of sediments hosting methane hydrate deposits on Hydrate Ridge, OR, I: Hydrological provinces. Earth Planet. Sci. Lett., 201, 525-540, doi: 10.1016/S0012-821X(02)00733-1. [Link]

Tryon, M. D. and K. M. Brown, 2001: Complex flow patterns through Hydrate Ridge and their impact on seep biota. Geophys. Res. Lett., 28, 2863-2866, doi: 10.1029/2000g1012566. [Link]

Tryon, M. D. and K. M. Brown, 2004: Fluid and chemical cycling at Bush Hill: Implications for gas- and hydraterich environments. Geochem. Geophys. Geosyst., 5, Q12004, doi: 10.1029/2004gc000778. [Link]

Tryon, M. D., K. M. Brown, M. E. Torres, A. M. Tréhu, J. McManus, and R. W. Collier, 1999: Measurements of transience and downward fluid flow near episodic methane gas vents, Hydrate Ridge, Cascadia. Geology, 27, 1075-1078, doi: 10.1130/0091-7613(1999)027<10 75:motadf $>2.3 . c 0 ; 2$. [Link]

Tryon, M. D., K. M. Brown, and M. E. Torres, 2002: Fluid 
and chemical flux in and out of sediments hosting methane hydrate deposits on Hydrate Ridge, OR, II: Hydrological processes. Earth Planet. Sci. Lett., 201, 541557, doi: 10.1016/S0012-821X(02)00732-X. [Link]

Vardaro, M. F., I. R. MacDonald, L. C. Bender, and N. L. Guinasso Jr., 2006: Dynamic processes observed at a gas hydrate outcropping on the continental slope of the Gulf of Mexico. Geo-Mar. Lett., 26, 6-15, doi: 10.1007/s00367-005-0010-2. [Link]

Wallmann, K., P. Linke, E. Suess, G. Bohrmann, H. Sahl- ing, M. Schlüter, A. Dählmann, S. Lammers, J. Greinert, and N. von Mirbach, 1997: Quantifying fluid flow, solute mixing, and biogeochemical turnover at cold vents of the eastern Aleutian subduction zone. Geochim. Cosmochim. Acta, 61, 5209-5219, doi: 10.1016/ S0016-7037(97)00306-2. [Link]

Wang, K. and E. E. Davis, 1996: Theory for the propagation of tidally induced pore pressure variations in layered subseafloor formations. J. Geophys. Res., 101, 1148311495, doi: 10.1029/96JB00641. [Link] 